\title{
THE WEALTH TRANSFERS OF BANKRUPTCY: SOME ILLUSTRATIVE EXAMPLES*
}

\author{
Merton H. Miller $\dagger$
}

\section{INTRODUCTION}

In a world where the views of Milton Friedman appear in one issue of Newsweek and those of Paul Samuelson in the next, many suppose that any two economists discussing the same topic inevitably come to opposite conclusions. Let it be clear from the outset, therefore, that such will not be the case here. In my opinion Dean Meckling's economic analysis of the corporate bankruptcy problem is sound in its essentials and even in most matters of detail. But it is also tightly condensed. Thus, the most useful contribution of a finance theorist to an interdisciplinary symposium of this kind may perhaps be to make more explicit the underlying economic model that Dean Meckling is using in his references to the wealth transfers, the incentive effects, and the inefficiencies that arise if the rights of creditors are weakened when default has occurred or is imminent. In doing so, I will rely heavily on simple-perhaps lawyers will think simple-minded-examples. In my experience, however, the discipline imposed by numbers, even simple ones, can cut down the confusions and ambiguities that inevitably creep into purely verbal discussions of events that unfold in an uncertain future.

\section{I \\ The Call-Option Analogy}

The particular path I will take to show the consequences of weakening the rights of creditors will be to invoke an analogy very popular in academic finance at the moment, comparing common stock in a firm that has creditors with priority to a call option. ${ }^{1}$ Ordinarily the stockholders in a levered corporation are considered to own the corporation as long as they meet their obligations as owners to the corporation's creditors. The call-option analogy por-

* A commentary on Meckling, Financial Markets, Default, and Bankruptcy: The Role of the State, Law \& Contemp. Prob., Autumn 1977, at 13 (1977). This paper was originally presented, in a slightly different form, at the Liberty Fund, Inc., Seminar on the Economics of Bankruptcy at the Law and Economics Center of the University of Miami School of Law (March 31-April 2, 1977).-Ed.

† Edward Eagle Brown Professor of Banking and Finance at the University of Chicago Graduate School of Business.

1. We owe this important insight to Fischer Black and Myron Scholes in their classic paper The Pricing of Options and Corporate Liabilities, 81 J. POL. Econ. 637 (1973). 
trays their position differently: the stockholders are considered to have the right to buy the corporation back from the creditors by paying them a "striking price"-that is, the coupons or principals coming due. If the value of the firm to the stockholders is greater than the striking price, then the stockholders will exercise their option by making the payment in order to retain control. If the value to the stockholders is less than the striking price, they will choose not to exercise their option and the firm's assets will remain with the creditors. In short, the call-option analogy portrays the loss of assets in foreclosure as the rejection of an option to buy.

Thanks to this analogy we can apply almost everything we know about the valuation of options - and that is a great deal-to the valuation of the shares in levered corporations. We know, for example, that if the underlying stock on which a call option is written suddenly becomes riskier, then-other things being equal-the option becomes more valuable. In other words, if the value to which the stock might climb can be raised at the expense of lowering the value to which it might fall, the change will benefit those who can purchase it at a preset price if it rises and refuse to purchase it if it falls. Similarly with a levered firm, if the stockholders can somehow manage to increase the riskiness of the firm, they increase the value of their equity interest. If their gamble succeeds-the value of the firm rises to its newly raised potential high-the stockholders can exercise their option, pay off the creditors, and pocket their winnings. If the risky venture fails-the value of the firm falls to its newly lowered potential low-the stockholders invoke their limited liability, walk away from the business, and leave the creditors holding the bag and whatever happens to be left in it.

Creditors, of course, are thoroughly aware of these and related temptations for the shareholders, and they take steps-mainly in the form of restrictive covenants and surveillance-to protect themselves from risk-increasing changes in the nature of a firm after their original bargain with it has been struck. These inevitable restrictions tend to be overlooked in those conventional discussions of leverage which stress finance as the art of gambling with OPM-Other People's Money. ${ }^{2}$

Gambling with other people's money would indeed be an artistic way of making a living, if only one could find the other people to supply the bankroll at the riskless rate of interest. In general one can't. But if a corporation is close to default, and if it can get court protection from foreclosure, it may have a close equivalent.

Court protection that permits stockholders to work their way out of difficulties and repay their obligations in full seems to be thoroughly in accord

2. The term "OPM" has long been part of the oral tradition among practitioners, though it is rarely found in the academic literature. Oddly enough, a leasing company by that name has recently been advertizing in the financial press. 
with American moral precepts; and it may even succeed in a significant fraction of the cases. But in fact it gives the stockholders a valuable call option at the expense of the creditors, who in effect are compelled to put up the OPM on terms they would otherwise never accept. ${ }^{3}$

\section{An Illustration}

A numerical illustration may help to fix these ideas in the reader's mind. For computational simplicity-and only for simplicity-the example will take all investors to be risk neutral and the market's required expected rate of return on all securities to be 10 percent. The latter assumption means that securities will only be bought if they are expected to realize 110 percent of their purchase price; and this provides the factor by which future expected values can be transformed into present market values.

Suppose, then, that a firm has unsecured debts of 1,000 about to come due and cannot meet its obligations. Assume that if the firm were to liquidate in an orderly fashion, its assets would be worth 800 . However, assume that if the firm stays in operation, there is a 50 -percent probability that it will increase its value next year to 1,210-more than enough to repay its debts in full with interest on the one-year deferral. But suppose that there is an equal chance that the firm will be worth only 220 if it has to be liquidated next year. Provided these two outcomes are mutually exclusive and exhaustive, it is clearly in the creditors' interest to foreclose immediately.

If the creditors were to let the stockholders continue to operate the firm, the creditors would have equal chances of getting either 1,100 (their outstanding loan plus interest at the market rate) or 220 (the liquidation value of the firm) next year. Combining next year's two potential values $([.5][1,100]+[.5]$ [220]) yields an expected future value of 660, which the expected 10-percent rate of return transforms into a present value of 600 . We can compute the expected future value of taking over the firm from the shareholders by substituting the expected future value of the firm for the expected loan repayment in the equation: $(.5)(1,210)+(.5)(220)=715$. This expected future value has a present value of 650 . Since both values are less than the present liquidation value of the firm, the creditors will indeed want to foreclose and liquidate. If they succeed, the stockholders will of course receive nothing.

Suppose, however, that the courts intervene to prevent the foreclosure, leaving the current stockholders in control of the firm. Before court interven-

3. Several of the conference participants pointed out to me that in practice, creditors often want the debtors to stay in control. If so, fine. They must presumably believe that they are getting something of value from the debtor in exchange for their option. The case I want to discuss, however, is one in which the creditors don't want to grant the option but have to grant it because the debtor has obtained court protection under chapter XI. 
tion the stockholders had an option to purchase the firm's assets, which are worth 800 , by fulfilling its debt obligations, which are 1,000. In short, they had a worthless option. Under court intervention the stockholders' plan for repaying the creditors gives the stockholders the option of buying the firm for 1,100 (the outstanding debt plus interest) next year. Since the firm has a 50 percent chance of being worth 1,210 next year, the stockholders' new option represents a 50-percent chance of earning 110 , which is worth $(.5)(110) / 1.10$ $=50$ today. Thus, the court intervention to prevent immediate foreclosure has transformed worthless stock into valuable stock. And where has this value come from? From the only place it can: the hides of the creditors. Note further that $\mathbf{5 0}$ is only the lower bound on the wealth transfer from creditors to stockholders. Since the firm's assets are assumed to be worth 800 in immediate liquidation, the creditors could afford to offer the stockholders as much as 200 of the proceeds of the liquidation and still be no worse off than if they were to accept the debtors' plan of repayment under court protection.

It is impossible to say, of course, where the actual negotiated settlement will fall between these limits. We do know, however, that in practice some cases fail to achieve voluntary agreement, and stockholders have to exercise their right of invoking court protection under chapter $\mathrm{XI}^{4}{ }^{\text {If }}$ this were to happen in our example, then the loss to the creditors of 200 would be greater than the gain to the stockholders-the characteristic sign of an inefficient economic arrangement. The creditors would bear not only the cost of the option that is transferred to the shareholders but also the full cost of the waste of productive resources involved in prolonging the life of a business that, from the economic point of view, is better off dead.

\section{III}

\section{EXample 2: The Viable Firm}

The first example was a firm that was better dead than alive. But many of the same principles apply even if an insolvent firm is viable, though the inefficiency will take a somewhat different form. Assume a set of conditions identical to our previous example except one, namely, that the liquidation value is substantially below the going-concern value of 650 .

If the stockholders can obtain court protection and keep control of the firm, they will, as we have seen, receive a free call option worth 50 at the expense of the creditors. Suppose, however, that the stockholders can also change their marketing or other operating strategies to alter the prospective payoff from an equal probability of 1,210 or 220 to a riskier one with an equal probability of 1,300 or 100 . This would lower the going-concern value of the firm to $[(.5)(1,300)+(.5)(100)] / 1.1=636.36$ from its present value of 650.

4. 11 U.S.C. \$8 701-99 (1970). 
An all-equity firm would not find such a change to be economic. The stockholders of a solvent levered firm, it is true, might be tempted to make such a change, since it raises the value of their equity from a 50-percent chance of earning 110 to a 50-percent chance of earning 200, an increase in present value of 40.91 , to 90.91 (= $=[.5][200] / 1.1)$. They get more "upside" potential at no cost to them on the "down" side, since they would simply choose not to exercise their option if the potential gains did not occur. The creditors' upside potential would remain the same $([.5][1,100])$, but their downside potential would be reduced to $(.5)(100)$, lowering their overall expected future returns to $(.5)(1,100)+(.5)(100)=600$ and the present value of that expectation to $600 / 1.1=545.45$.

Ordinarily, the stockholders are prevented from making this change by the lenders' covenants, violation of which would make their loans due and payable immediately. But court protection has removed this sanction in our example of an insolvent firm, and if the court permits the stockholders to adopt the riskier policy, they can raise the value of the free call option they have already received. ${ }^{5}$ Once again, the loss to the creditors $(600-545.45=$ $54.55)$ is greater than the gain to the stockholders, with the difference representing the loss from the uneconomic switch in policy.

Why would the court sanction such inefficiency? Presumably it wouldn't if the issues were posed in those terms. But the court will typically see only a single-valued estimate, to wit, the debtors' proposed plan of repayment. In our example the plan consists of a set of policies that, if successful, will yield a payoff of 1,300 next period. Nor is the prospect obviously forlorn or foolish. The probability of success is substantial-50 percent in this case. This high probability, incidentally, should also illustrate why the success of many plans under chapter XI cannot be taken as evidence of the efficiency of the procedure.

\section{IV \\ Example 3: The Lenders' Reaction}

In the face of bankruptcy rules and procedures that permit or even encourage the transfer of wealth from creditors to shareholders, how should we expect lenders to respond? One response, of course, is to demand higher interest at the time the loans are made to compensate the lenders for their lower expected recovery in bankruptcy.

For simplicity of calculation let us consider a simpler bankruptcy rule than the chapter XI plan of the previous examples. Suppose that we instituted a

5. Note that while the stockholders have an equity interest of 90.91 , thanks to court protection from foreclosure, they would clearly be unable to find a merger partner if that partner had to assume its share of the liabilities at face value. 
minimum exemption level of assets for the stockholders in bankrupt corporations, as there is in personal bankruptcies. Before the institution of this rule, debt securities promising 1,100 next year from a venture whose gross payoffs will be 1,300 or 100 with equal probability would sell currently for $\mathbf{5 4 5 . 4 5}$ $(=[(.5)(1,100)+(.5)(100)] / 1.1)$. The promised or coupon rate of interest would thus be slightly over 100 percent, although the expected rate would still be the 10 percent that has been taken as the required return on all securities in our illustrations. After the institution of our exemption rule, the present value of the debt securities would change to $(.5)(1,100) / 1.1$, since the stockholders would retain the assets worth 100 in the case of default. This lowers the current price of the debt securities to 500, hence raising their promised rate of interest to 120 percent. The value of the equity would be $136.36=$ $[(100)(.5)+(1300-1100)(.5)] / 1.1$. If, therefore, the assets to operate the venture could be purchased for 636.36 , the venture would be entirely feasible from the standpoint of both the stockholders and the creditors. It is precisely because the rates of return required by the market can adjust in this way to virtually any pattern of endgame rules that the rules themselves are of little concern. The wealth transfers (and associated inefficiencies) that we have been discussing have occurred in cases where the rules have changed, in effect, after the game has started.

Although ex ante yield adjustments of the kind described can compensate lenders for almost any pattern of bankruptcy rules, such adjustments may not always prove to be the most efficient solution from the lenders' point of view. To compensate lenders only for the wealth transfers of court-protected repayment plans might not be inefficient. But, as we have seen, the lenders would also have to be compensated for the inefficiencies and dead-weight losses that they bear when claims are restructured under court supervision. Interest rates high enough to compensate lenders for bearing these deadweight costs would make it uneconomic for the firm to borrow. In the language of finance, increasing the leverage and compensating the borrowers would cause the value of the firm to fall.

The yield adjustments would thus reduce the waste of the court-supervised bankruptcy process by the Procrustean method of reducing the volume of lending. Given the specialized human and nonhuman capital in the lending industry, however, it is hard to believe that any sizeable contraction in the volume of loans to corporations would or should occur, even in the face of restrictions on the rights of creditors in bankruptcy that are far more severe than any currently under consideration.

If there is a chance that the rights of creditors after insolvency will be curtailed, or if the costs of the court-supervised bankruptcy process are high, the creditors will adopt methods that enable them to assert their rights before the firm's affairs have deteriorated to the point of default. There is after all 
nothing sacred in the trigger that transfers the firm to the creditors precisely when a payment of interest or principal is missed. Once the call-option analogy is understood, it becomes clear that a trigger level for exercising the option can be set by mutual agreement for any value of the firm, including one substantially above the default point (as is routinely done, for example, in margin transactions in securities). ${ }^{6}$ In other words, creditors can demand loan contracts under which stockholders forfeit control of the firm as soon as it reaches a value that is above the level at which they would default.

That the financial and legal communities have the ingenuity to reorganize by such a voluntary agreement without court-supervised bankruptcy can be proved-if proof is needed-by the recent renegotiated agreement between TWA and its senior creditors. The following account of the agreement appeared in the Wall Street Journal: ${ }^{7}$

NEW YORK-Trans World Airlines said it and its senior lenders reached arrangements providing for the relaxation of certain of the financial tests and covenants required of the airline under its existing financial agreements. These include certain conditions governing TWA's ability to borrow under its revolving credit agreement, the airline said.

The arrangements also would reduce the current borrowing limit to $\$ 200$ million from $\$ 246$ million.

The arrangements would secure TWA's outstanding senior debt, currently $\$ 572$ million, under a mortgage covering substantially all TWA aircraft and aircraft engines. Provision also was made for the termination or suspension of the mortgage in the event TWA's debt-to-asset ratio, as defined, drops below $50 \%$, and if the company's net worth rises above $\$ 400$ million as of either June 30 or Dec. 31 of any year.

The mortgage would be reinstated whenever net worth becomes less than $\$ 350$ million or the ratio of debt to assets becomes greater than $55 \%$. As of last Dec. 31 , the debt-to-asset ratio was about $55 \%$ and the company's net worth was about $\$ 377$ million, TWA said.

The airline said that the added flexibility in using its revolving credit is expected to save it over $\$ 2$ million this year.

The new arrangements were agreed to after TWA disclosed that in 1976 its net income was $\$ 36.8$ million, compared with a 1975 loss of $\$ 86.3$ million.

\section{Conclusion}

To summarize: I have used the analogy of the call option and some simple numerical examples to throw what I hope is some additional light on the conflict of interest between creditor and debtor in bankruptcy that is a running theme throughout Dean Meckling's essay. In particular, I have tried to show how permitting stockholders to claim court protection and thereby re-

6. For a discussion of safety levels and their implications for the value of debt and equity securities see Black \& Cox, Valuing Corporate Securities: Some Effects of Bond Indenture Provisions, J. Finance 351 (1976).

7. Wall St. J., Mar. 2, 1977, at 23. 
tain control of a corporation in default would amount to giving them a call option at the expense of the creditors. Furthermore, the cost to the creditors may be greater than the gain to the shareholders, because the arrangement may encourage wasteful business policies. Fortunately for the creditors, however, they should be able to adapt to any new weakening of their rights, after the initial shock, either by raising the risk premiums they demand on new loans or, as the options analogy suggests, by setting trigger levels that permit them to regain the initiative before a default actually occurs. 